\title{
Computer-Aid Design of Novel Sulfonamide Derivatives as EGFR Kinase Inhibitors for Cancer Treatment
}

\author{
Souad Akili', Djamila Ben Hadda², Yasser Bitar ${ }^{1}$, Abdulkarim Najjar ${ }^{3}$, Mustapha Fawaz Chehna ${ }^{*}$ \\ ${ }^{1}$ Department of Pharmaceutical Chemistry and Drug Control, Faculty of Pharmacy, University of Aleppo, Aleppo, Syria \\ ${ }^{2}$ Department of Pharmaceutical Chemistry and Drug Control, Faculty of Pharmacy, Ebla Private University, Aleppo, Syria \\ ${ }^{3}$ Department of Pharmaceutical Chemistry, Institute of Pharmacy, Martin Luther University, Halle, Germany \\ Email: ^mf.chehna@gmail.com
}

How to cite this paper: Akili, S., Hadda, D.B., Bitar, Y., Najjar, A. and Chehna, M.F. (2021) Computer-Aid Design of Novel Sulfonamide Derivatives as EGFR Kinase Inhibitors for Cancer Treatment. International Journal of Organic Chemistry, 11, 171-186.

https://doi.org/10.4236/ijoc.2021.114012

Received: July 24, 2021

Accepted: November 9, 2021

Published: November 12, 2021

Copyright $\odot 2021$ by author(s) and Scientific Research Publishing Inc. This work is licensed under the Creative Commons Attribution International License (CC BY 4.0).

http://creativecommons.org/licenses/by/4.0/

\begin{abstract}
Several novel sulfonamide-derivatives were designed and studied their physicochemical properties to develop novel kinase inhibitors. Therefore, molecular docking was performed for the designed compounds against epidermal growth factor receptor (PDB ID: 2ITY) to identify new drug candidates for treating cancer. Binding free energy was calculated by Molegro virtual docker (MVD) to select the most promising hits. The corresponding docking score values into EGFR of $4 \mathrm{~b}$ gave the best energy docking $-128.819 \mathrm{Kcal} / \mathrm{mol}$. The identified hits can serve as starting points for further chemical synthesis and optimization to develop new potent anticancer agents.
\end{abstract}

\section{Keywords}

Sulfonamide, Anticancer, EGFR, 2ITY, Kinases, Molecular Docking, Molegro Virtual Docker, MVD, MarvinSketch

\section{Introduction}

Cancer is a worldwide health problem and the most deadly disease in humans [1], and it is considered the second leading cause of mortality after cardiovascular diseases [2]. Various conditions and factors can turn normal cells into cancer cells by altering the normal function of a wide spectrum of apoptotic, and signal transduction pathways. This is called loss of differentiation [3]. There are several methods for treating cancer such as Surgery, Chemotherapy, Hormonal therapy, Immunotherapy [3] [4], and Phototherapy [5].

Kinase enzymes are motivated the transfer of phosphate groups from ATPs to 
certain substrates, a process is called phosphorylation. Kinases are part of the phosphotransferases family which is a subclass of transferases. Kinases are used widely to control complex processes and transfer signals in cells. Protein kinases have a role in most of the signal transduction in eukaryotic cells and control many other cellular processes, including cytoskeletal rearrangement, transcription, cell cycle progression, metabolism, cell movement, apoptosis, and differentiation [6].

One of the kinase families is Protein tyrosine kinases (PTKs) that are known to be activated in cancer cells and to drive tumor growth, progression, angiogenesis, and metastasis. PTKs are involved in the transfer of phosphate in ATP to tyrosine residues on protein substrates, which is known as tyrosine phosphorylation [6]. Several TKs play essential roles in growth, cell proliferation, signaling, differentiation, survival, metabolism, and apoptosis [7] [8]. Epidermal growth factor receptor (EGFR) is a member of the tyrosine kinase family and is usually overexpressed in several types of cancer, such as non-small-cell lung cancer (NSCLC), breast, esophageal, head, cervical, and neck cancer [9] [10]. In NSCLC, studies have demonstrated that the EGFR is overexpressed in $40 \%$ to $80 \%$ of cases, depending on histology [11]. Also, mutations in epidermal growth factor receptor have been discovered in association with some lung cancers [12].

Kinase inhibitors can be classified into three classes depending on their binding mode: type I inhibitors are ATP-competitive compounds targeting the ATP binding site in the active form of a kinase, type II inhibitors are ATP-competitive compounds that also target the ATP binding site but in the inactive form of a kinase, and type III inhibitors are allosteric inhibitors that are not ATP-competitive since they bind to binding sites far from the ATP binding site [13].

EGFR-TK inhibitors are the second most main drug targets that have been approved for the therapy of non-small cell lung cancer, and this catalyzed inhibition of EGFR signaling may not only be active in anti-proliferative effects and have also been increased sensitivity to cytotoxic therapies [14]. Therefore, blocking tyrosine kinase activity represents a rational approach to cancer therapy [7].

Among the broad range of compounds tested as potential anticancer agents, derivatives of sulfamide have attracted reasonable attention [15]. Sulfonamide derivatives include an important class of drugs with different biological activities [16], and many of them are widely used in therapy as antihypertensive, antibacterial, anti-inflammatory, anti-thyroid [17] [18], and hypoglycemic [19], diuretic and receptor tyrosine kinase inhibitors [1]. Recently, a host of structurally novel sulfonamide derivatives have been reported to show anticancer activity in vivo and/or in vitro [20] [21].

Molecular docking is in silico structure-based method vastly used in drug discovery. Docking enables the identification of new compounds of therapeutic benefit, delineating structure-activity relationships (SAR), or predicting ligand-target interactions at a molecular scale, without previous information about the chemical structure of other target modulators [22] [23]. The docking 
process includes two steps: prediction of the ligand conformation moreover its position and orientation within these sites (usually called as pose) and estimate the binding affinity [24]. The lock-and-key theory suggested by Fischer, which be the early explanation for the ligand-receptor binding mechanism, where the ligand suits the receptor-like lock and key.

The current study aims to design novel sulfonamide derivative EGFR inhibitors using computational drug design approaches. The identified hits can serve as starting points for further chemical synthesis and optimization to develop new potent anticancer agents.

\section{Materials and Methods}

Protein Data Bank (PDB), PubMed and software's like Marvin sketch version 21.2, ChemSketch version 14.01, and Molegro Virtual Docker (MVD) version 2011.4.3 were implemented to within the current study.

\subsection{EGFR Structure}

The 3D crystal structure of EGFR (PDB ID: 2ITY) domain was retrieved from PDB and has a resolution of $3.42 \AA$. The kinase domain consists of 327 residues between 696 - 1022 residues. The resolved EGFR structure was co-crystallized as holoform with a known kinase inhibitor Iressa (Figure 1).

The EGFR was prepared by imported in MVD, then a list of residues is shown. All residues with potential errors are highlighted on the list and emphasized in the $3 \mathrm{D}$ view with red or yellow spheres pointing to the two different kinds of residue errors (such as missing atoms or incorrect bonds) and corrected in those cases where it had failed, and water molecules were removed from the crystal structure of the protein.

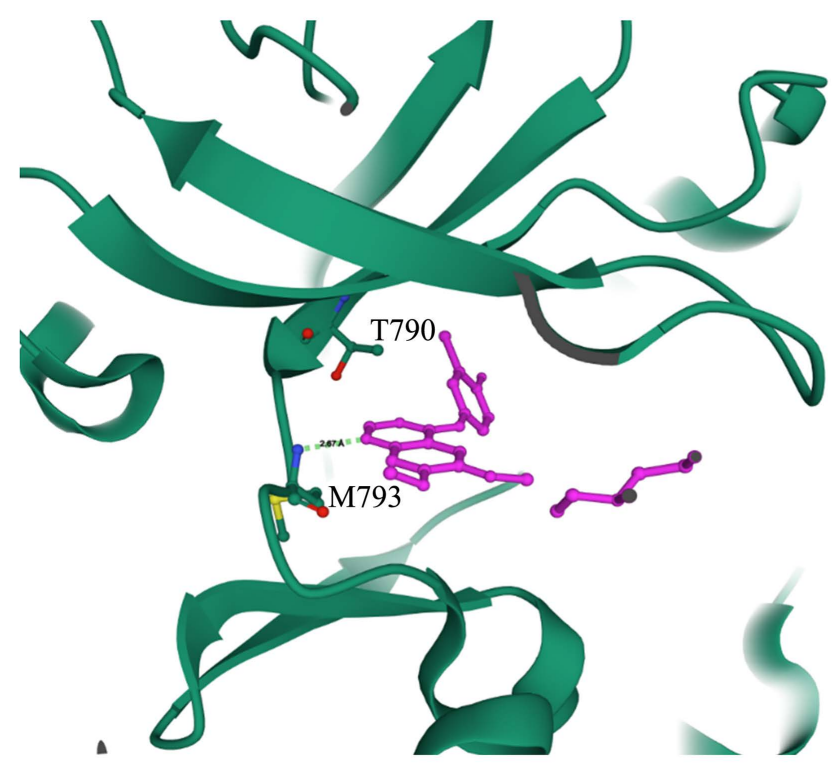

Figure 1. Co-crystal structure of the EGFR (PDB ID: 2ITY) kinase domain in complex with Iressa. 


\subsection{Define the Binding Pocket}

The binding pocket was defined using the co-crystallized ligand as a center of the pocket, which had a volume of $241.664 \AA$, and fitted to the polar surface area for designed compounds, (Figure 2).

\subsection{Compounds Preparation}

Structures of designed compounds were drawn and optimized by using Marvin Sketch and saved as mol2. The preparation of compounds was performed using the default setting to assign bonds, assign bond orders and hybridization, create explicit hydrogens, assign charges (calculated by MVD), detect flexible torsions in ligands, and assign tripos atom types.

\subsection{Molecular Docking}

The Molecular Docking was performed in MVD. The following parameters were used for docking in the EGFR kinase (Figure 3).

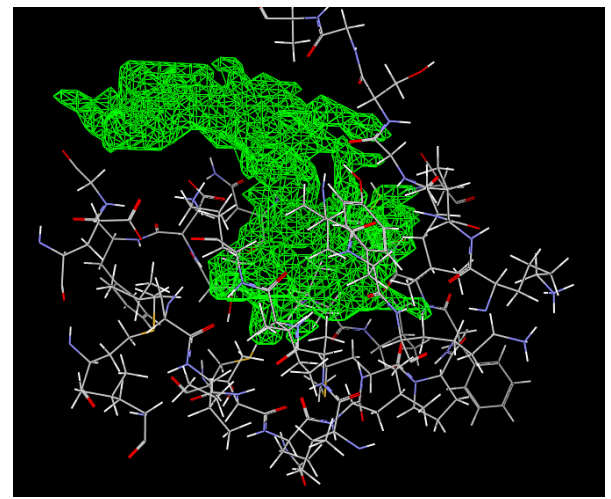

Figure 2. EGFR binding pocket (PDB ID: 2ITY) used to dock the designed compounds.

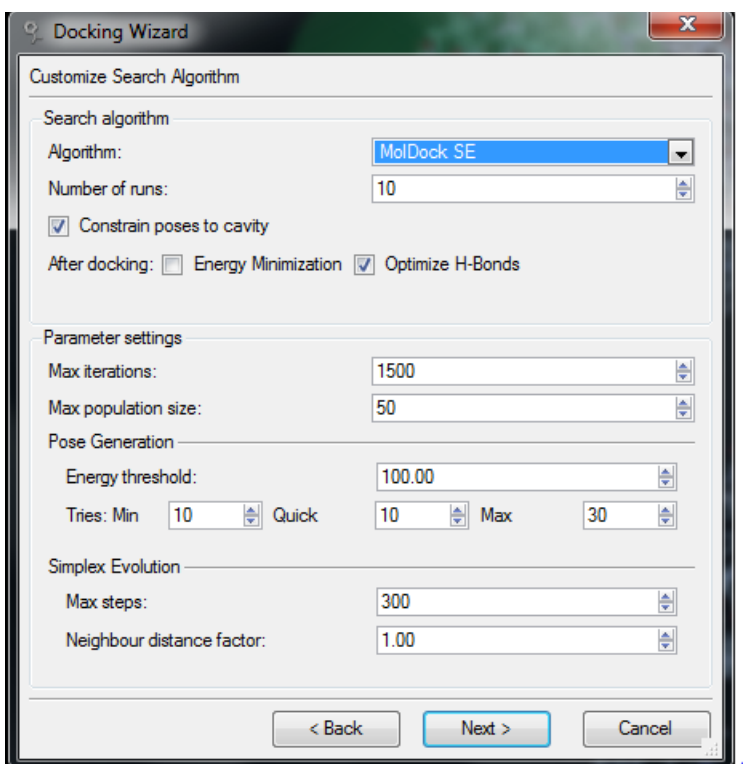

Figure 3. Parameters of Molegro Virtual Docker. 
Plants score (GRID) function was used with a grid resolution of $0.30 \AA$ and a binding site radius of $15 \AA$ with respect to the origin of the respective cavities. The "MolDock SE" searching algorithm 10 runs using a maximum of 1500 iterations with a total population size of 50 was applied. The energy threshold used for the minimized final orientation is 100 . The simplex evaluation with 300 maximum steps of neighbor distance factor 1 was completed. Docker uses the MolDock docking engine to predict ligand-protein interactions. MolDock is based on a new hybrid search algorithm called guided differential evolution [25].

The results of docking compounds with the receptors were compared with two standard compounds are shown in (Figure 4) that were synthesized by Ihmaid $\mathrm{S}$ and el, which the first standard compound

((E) $-N-\{2-[2-(2,4-D i h y d r o x y b e n z y l i d e n e)$ hydrazine-1 -carbonyl] pheny\} furan-2carboxamide), docked with EGFR receptor and had $\mathrm{IC}_{50}$ value $85.4 \pm 0.32 \mathrm{nM}$, and the second standard compound

( $N$-\{2-[(4-Sulfamoylpheny) carbamoyl] phenyl\} furan-2-carboxamide), docked with tubulin receptor and had $\mathrm{IC}_{50}$ value $31.2 \pm 0.12 \mathrm{nM}$ [26].

The PLANTS scoring function (PLANTS Score) used by MVD is derived from the PLANTS scoring function originally proposed by Korb et al.

The docking scoring function, $E_{\text {plantsscore }}$ is defined by the following energy terms:

$$
E_{\text {plantsscore }}=f_{P L P}+f_{\text {clash }}+f_{\text {tors }}+c_{\text {site }}-20
$$

$f_{P L P}$ is a piecewise linear potential taking into account protein-ligand interactions.

$f_{\text {clash }}$ and $f_{\text {tors }}$ take into account internal ligand clashes and torsional contributions for the flexible bonds in the ligand.

The $c_{\text {site }}$ term specifies a penalty that is calculated if a ligand conformation (pose) is located outside the binding site.

The -20 energy offset was originally needed for the PLANTS search algorithm and is included here in order for PLANTS scores to be comparable with the original PLANTS implementation.<smiles>NS(=O)(=O)c1ccc(NC(=O)c2ccccc2NC(=O)c2ccco2)cc1</smiles>

(a)<smiles>Cc1cc(/C=N/NC(=O)c2ccccc2NC(=O)c2ccco2)c(O)cc1O</smiles>

(b)

Figure 4. (a) Reference drug 1 structure, (b) reference drug 2 structure. 


\section{Result and Discussion}

\subsection{Sulfonamide Derivatives}

The core scaffold of the sulfonamide shown in (Figure 5) was used to design several derivatives in the current study. Two modification sites were considered on the main scaffold represented by $R_{1}$ and $R_{2}$ (Table 1 ). Whereby the substituents of the $R_{1}$ were changed in order to study the role of the amine in binding with the receptor and containing aromatic rings with different substituents. As for the substituents of the $\mathrm{R}_{2}$, the change of the aromatic ring associated with the amide group was studied.

\subsection{Physicochemical Properties of Designed Sulfonamide Derivatives}

The physicochemical properties were predicted using Marvin Sketch from chemical structures and placed in (Table 2). The Calculators and predictors in Marvin Sketch generate values for properties of a particular chemical structure. A calculation is something that generates a value for that structure (e.g. number or atoms, molecular weight) whereas a prediction generates an estimated value for a property that cannot be precisely determined, except by experimental methods (e.g. $\log \mathrm{P}, \mathrm{pKa}$, solubility), though this distinction is often somewhat blurred. There are usually multiple ways to generate a prediction (e.g. different computer algorithms and/or different parameters) and different ways will generate different values.

Rule of five (ROF) is a rule of thumb to evaluate drug likeness or determine if a chemical compound with a certain pharmacological or biological activity has properties that would make it a likely orally active drug in humans. The rule describes molecular properties important for a drug's absorption, distribution, metabolism and excretion in the human body [27]. Therefore, to analyze the drug-like characteristics, Lipinski's rule of five was considered, molecules were evaluation using Lipinski's rule of five was considered, which specifies that a probable drug molecule should have molecular weight $\leq 500, \log \mathrm{P} \leq 5$, polar surface area $\leq 140 \AA$, hydrogen bond acceptors $\leq 10$, and donor $\leq 5$ [28]. As the rule of five compliance ensures bioavailability, the designed library molecules were assumed to have better intestinal permeability. Several pharmacophores were proposed on the scaffold by introducing different function groups as hydrogen donors/acceptors. The lipophilicity of the compounds $\log \mathrm{P}$ has a significant impact on the permeability of the cell membrane. The intermediate polar surface area (PSA) of compounds plays a role in cell internalization. Therefore,

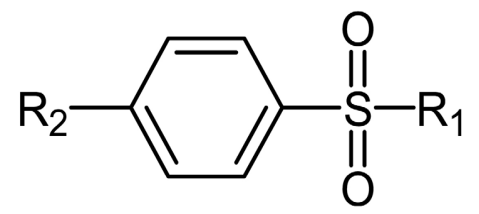

Figure 5. Scaffold of sulfonamide. 
S. Akili et al.

Table 1 . $R_{1}$ and $R_{2}$ substitutions on sulfonamide scaffold considered in the study.

\begin{tabular}{ll}
\hline & $\mathrm{R}_{2}$ \\
la & $\mathrm{Ph}-\mathrm{C}-\mathrm{H}-$
\end{tabular}

16<smiles>CNC(=O)c1ccccc1</smiles>

$1 c$<smiles>CNC(=O)c1ccccc1</smiles>

$2 \mathrm{a}$<smiles>CNC(=O)c1ccccc1</smiles>

$2 \mathrm{~b}$

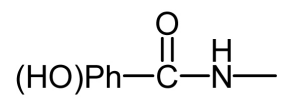

$2 c$

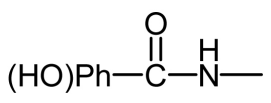

$3 a$<smiles>CN1C(=O)c2ccccc2C1=O</smiles>

$3 \mathrm{~b}$

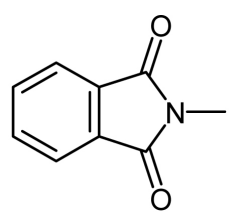

$3 c$

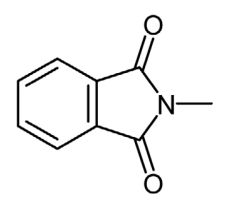

$3 d$

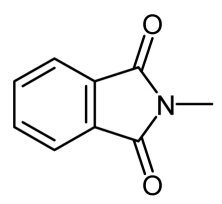

$4 \mathrm{a}$

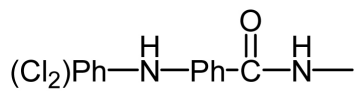

$4 b$

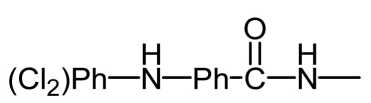

$\mathrm{R}_{1}$

$\mathrm{OH}$

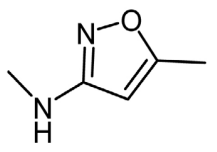

$\mathrm{Ph}-\stackrel{\mathrm{O}}{\mathrm{C}}-\mathrm{H}-$

$\mathrm{OH}$

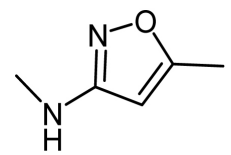

(HO) $\mathrm{Ph}-\stackrel{\mathrm{O}}{\mathrm{C}}-\mathrm{H}-$

$\mathrm{OH}$
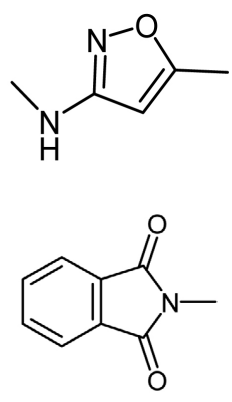

$\mathrm{NH}_{2}$

$\mathrm{OH}$

$8 \mathrm{~b}$

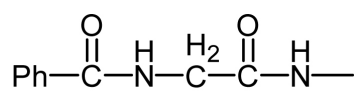

Tc

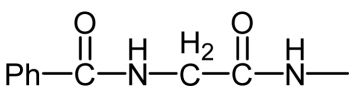

$8 a$

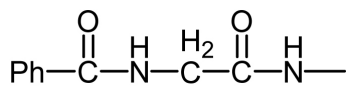

$7 \mathrm{~b}$
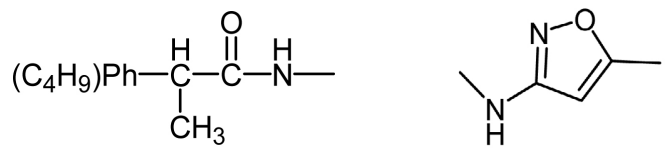

$5 c$
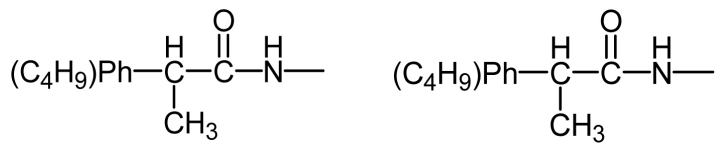

$6 a$

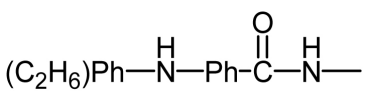

$6 \mathrm{~b}$

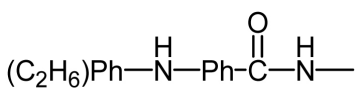

$6 c$
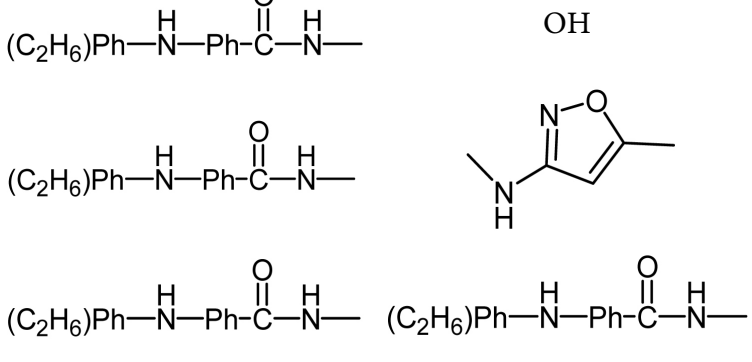

$\mathrm{OH}$

$\mathrm{OH}$<smiles>CNc1cc(C)on1</smiles><smiles>CNC(=O)CNC(=O)c1ccccc1</smiles><smiles>CNC(=O)[Pb]C(=O)OC</smiles>

$\mathrm{OH}$

$8 c$<smiles>CNC(=O)[Pb]C(=O)OC</smiles><smiles>CNc1cc(C)on1</smiles>

$\mathrm{NH}_{2}$

ac $\quad\left(\mathrm{Cl}_{2}\right) \mathrm{Ph}-\stackrel{\mathrm{H}}{\mathrm{N}}-\mathrm{Ph}-\stackrel{\mathrm{O}}{\mathrm{C}}-\mathrm{H}-\quad\left(\mathrm{Cl}_{2}\right) \mathrm{Ph}-\stackrel{\mathrm{H}}{\mathrm{N}}-\mathrm{Ph}-\stackrel{\mathrm{O}}{\mathrm{C}}-\stackrel{\mathrm{H}}{\mathrm{N}}-$

DOI: 10.4236/ijoc.2021.114012

177

International Journal of Organic Chemistry 
Table 2. Physicochemical properties of designed compounds.

\begin{tabular}{|c|c|c|c|c|c|c|c|c|c|}
\hline Ligand & $\begin{array}{c}\text { Molecular } \\
\text { weight }\end{array}$ & $\log \mathrm{P}$ & $\log D$ & $\begin{array}{c}\text { Polar } \\
\text { surface } \\
\text { area }\end{array}$ & $\begin{array}{c}\text { Molecular } \\
\text { surface } \\
\text { area }\end{array}$ & $\begin{array}{c}\mathrm{H} \\
\text { donor }\end{array}$ & $\begin{array}{c}\mathrm{H} \\
\text { acceptor }\end{array}$ & $\begin{array}{c}\text { Rotatable } \\
\text { bonds }\end{array}$ & $\begin{array}{l}\text { Lipinski's } \\
\text { rules } \\
\text { violation }\end{array}$ \\
\hline $1 \mathrm{a}$ & 277 & 1.9 & -0.36 & 91.85 & 322.98 & 2 & 4 & 3 & 0 \\
\hline $1 b$ & 357 & 2.88 & 1.88 & 109.68 & 423.51 & 2 & 5 & 4 & 0 \\
\hline $1 c$ & 376 & 5.42 & 5.42 & 66.58 & 463 & 2 & 2 & 5 & 1 \\
\hline $2 \mathrm{a}$ & 273 & 1.62 & -0.76 & 112.08 & 341.99 & 3 & 5 & 3 & 0 \\
\hline $2 b$ & 373 & 2.6 & 1.48 & 129.91 & 433.91 & 3 & 6 & 4 & 0 \\
\hline $2 c$ & 412 & 3.55 & 2.25 & 141.18 & 470.22 & 4 & 6 & 4 & 1 \\
\hline $3 a$ & 321 & 1.42 & -4.46 & 129.15 & 352.68 & 3 & 5 & 4 & 0 \\
\hline $3 b$ & 383 & 2.09 & 1.07 & 117.96 & 425.3 & 1 & 6 & 3 & 0 \\
\hline $3 c$ & 468 & 2.5 & -5.66 & 175.32 & 510.51 & 4 & 8 & 6 & 1 \\
\hline $3 d$ & 302 & 1.18 & 1.18 & 97.54 & 375.86 & 1 & 4 & 2 & 0 \\
\hline $4 a$ & 450 & 4.49 & 4.49 & 92.34 & 497.92 & 2 & 7 & 6 & 0 \\
\hline $4 \mathrm{~b}$ & 530 & 6.11 & 5.11 & 109.68 & 605.78 & 2 & 7 & 7 & 1 \\
\hline $4 c$ & 728 & 8.27 & 7.13 & 124.78 & 798.4 & 4 & 10 & 10 & 1 \\
\hline $5 a$ & 361 & 4.17 & 1.91 & 91.85 & 473.42 & 2 & 4 & 6 & 0 \\
\hline $5 b$ & 441 & 5.15 & 4.55 & 109.68 & 572.36 & 2 & 5 & 7 & 1 \\
\hline $5 c$ & 548 & 8 & 6.88 & 100.72 & 744.84 & 2 & 4 & 10 & 1 \\
\hline $6 a$ & 396 & 5.39 & 3.13 & 103.88 & 488.65 & 3 & 5 & 5 & 1 \\
\hline $6 \mathrm{~b}$ & 476 & 6.37 & 5.36 & 121.71 & 587.5 & 3 & 6 & 6 & 1 \\
\hline $6 c$ & 618 & 10.44 & 9.3 & 124.78 & 781.3 & 4 & 6 & 8 & 1 \\
\hline $7 a$ & 334 & 0.83 & -1.44 & 120.95 & 387.35 & 3 & 5 & 5 & 0 \\
\hline $7 \mathrm{~b}$ & 414 & 1.81 & 0.8 & 138.78 & 488.23 & 3 & 6 & 6 & 0 \\
\hline $7 \mathrm{c}$ & 494 & 1.31 & 0.17 & 158.92 & 579.77 & 4 & 6 & 8 & 1 \\
\hline $8 a$ & 335 & 2.25 & -0.13 & 109.77 & 434.89 & 1 & 5 & 5 & 0 \\
\hline $8 b$ & 416 & 2.71 & 1.86 & 127.6 & 548.54 & 1 & 6 & 6 & 0 \\
\hline $8 c$ & 334 & 1.67 & 1.67 & 115.56 & 441.42 & 2 & 4 & 5 & 0 \\
\hline
\end{tabular}

results showed that most of the designed ligands are not violating the rule of five and may be developed as potential drug candidates. The partial charge of designed compounds was calculated to each atom by Marvin Sketch, (Figure 6).

\subsection{Molecular Docking Results}

The list of compounds was docked into the EGFR receptor binding pocket using the validated docking methods. Docking results tabulated between The EGFR binding pocket and the derivatives of sulfonamide are shown (Table 3).

Validation docking method

Validation of docking was used to ensure orientation and position of ligand 

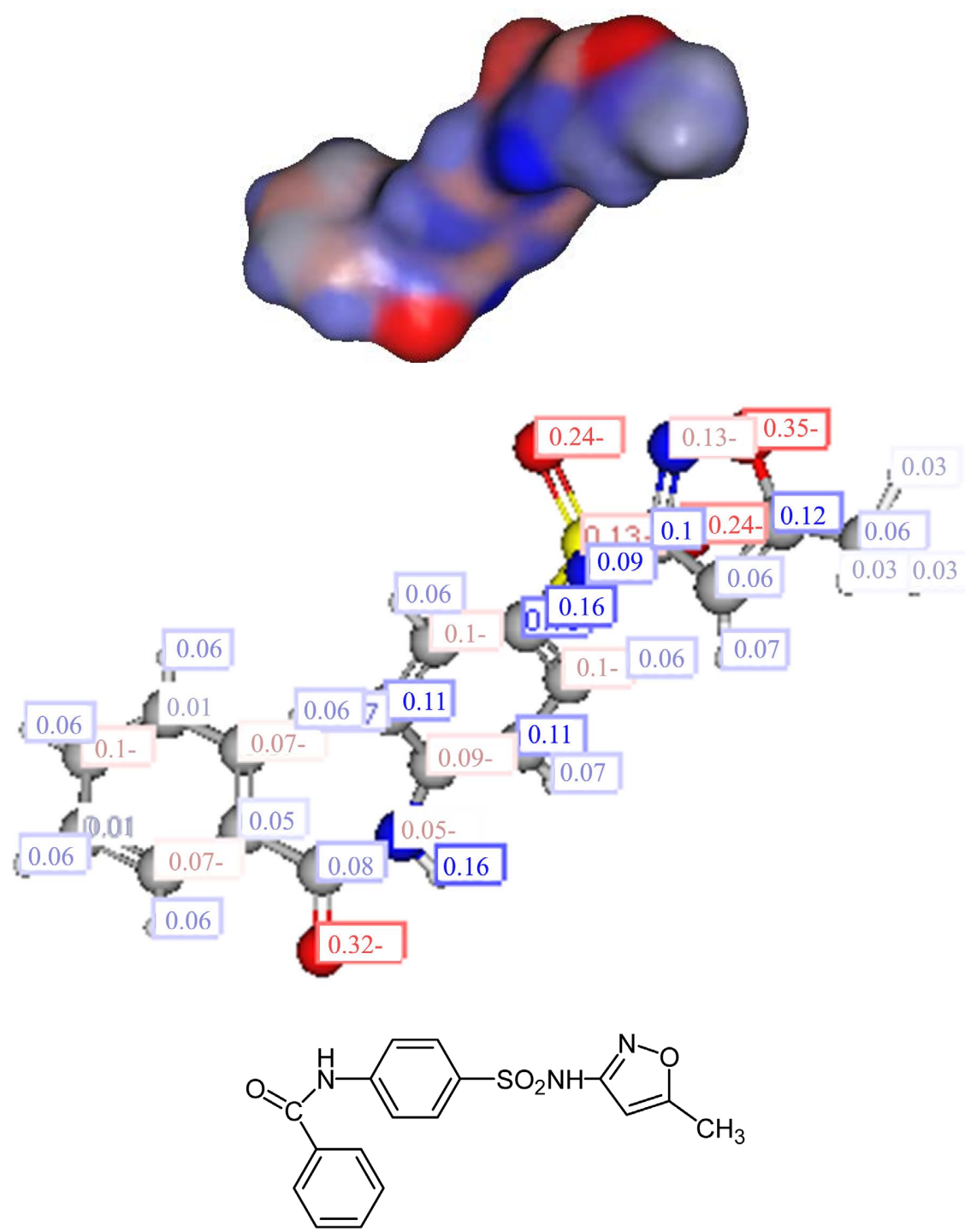

Figure 6. Partial charges of $1 \mathrm{~b}$ compound which studied by Marvin sketch.

binding obtained from docking studies by MVD program. Therefore, the parameters must be validated by re-dock the native ligand into the crystal structure (PDB ID: 2ITY). After that, it was extracted and re-docked into the binding pocket to generate the X-ray binding mode. The ability of the docking algorithm to generate the active biding mode of the ligands was evaluated by calculating the RMSD (Root Mean Square Deviation) between the docking solutions and the $\mathrm{X}$-ray binding mode. RMSD $<2 \AA$ considered as a threshold in the computer-aided drug design.

The RMSD value for the top-ranked docking solution of ligand was 1.17949. Thus, the applied docking methods were able to generate the X-ray binding mode of the ligand.

The interactions between the binding pocket residues of the EGFR receptor and the sulfonamide derivatives together with energy docking are shown in $\mathrm{Ta}$ ble 4. 
Table 3. The energy docking of ligands with receptors.

\begin{tabular}{|c|c|}
\hline Ligand & Energy docking with $2 \mathrm{ITY}(\mathrm{Kcal} / \mathrm{mol})$ \\
\hline $4 \mathrm{~b}$ & -128.819 \\
\hline $7 \mathrm{~b}$ & -127.523 \\
\hline $6 c$ & -121.849 \\
\hline $6 \mathrm{~b}$ & -117.124 \\
\hline $5 c$ & -112.43 \\
\hline $4 \mathrm{c}$ & -111.427 \\
\hline $3 b$ & -108.688 \\
\hline $5 b$ & -108.364 \\
\hline $3 c$ & -104.139 \\
\hline $3 \mathrm{~d}$ & -103.186 \\
\hline $4 a$ & -102.175 \\
\hline $8 \mathrm{~b}$ & -100.42 \\
\hline Standard 2 & -99.6243 \\
\hline Iressa & -98.8651 \\
\hline $7 c$ & -98.4738 \\
\hline Standard 1 & -93.5665 \\
\hline $3 a$ & -93.0394 \\
\hline $1 b$ & -91.9394 \\
\hline $2 b$ & -88.2345 \\
\hline $6 a$ & -87.3354 \\
\hline 1a & -82.1471 \\
\hline $2 c$ & -81.6785 \\
\hline $8 \mathrm{a}$ & -80.8588 \\
\hline $1 c$ & -80.2854 \\
\hline $8 \mathrm{c}$ & -79.8328 \\
\hline $5 a$ & -78.3595 \\
\hline $7 \mathrm{a}$ & -74.1276 \\
\hline $2 a$ & -72.206 \\
\hline
\end{tabular}

Table 4. Interaction of the amino acids in 2ITY with ligands.

\begin{tabular}{cccccc}
\hline ligand & Residue & Interaction & Distance $(\AA)$ & Energy & Van der Waals interaction \\
\hline \multirow{4}{*}{ 1a } & Met793 & O-H & 3.1 & -2.5 & \\
& Asp855 & O-H & 3.04 & -2.5 & - \\
& Asp855 & O-H & 2.91 & -1.55509 & \\
& Thr854 & O-H & 2.9 & -2.5 & \multirow{2}{*}{ Pro794 } \\
\hline \multirow{2}{*}{ 1b } & Met793 & O-H & 2.66 & -2.5 & \\
& Pro794 & N-H & 3.057 & -0.701673 & \\
\hline
\end{tabular}




\section{Continued}

\begin{tabular}{|c|c|c|c|c|c|}
\hline $1 \mathrm{c}$ & Asp855 & $\mathrm{N}-\mathrm{H}$ & 2.94 & -2.5 & Asp855, Pro794 \\
\hline \multirow{4}{*}{$2 \mathrm{a}$} & Met793 & $\mathrm{O}-\mathrm{H}$ & 2.8 & -2.5 & \multirow{4}{*}{-} \\
\hline & Asp855 & $\mathrm{O}-\mathrm{H}$ & 3.05 & -1.90438 & \\
\hline & Thr854 & $\mathrm{O}-\mathrm{H}$ & 2.9 & -2.5 & \\
\hline & Lys745 & $\mathrm{O}-\mathrm{H}$ & 3 & -2.5 & \\
\hline \multirow{3}{*}{$2 b$} & Gln791 & $\mathrm{O}-\mathrm{H}$ & 2.6 & -2.5 & \multirow{3}{*}{-} \\
\hline & Met793 & $\mathrm{O}-\mathrm{H}$ & 2.98 & -1.3688 & \\
\hline & Met793 & $\mathrm{O}-\mathrm{H}$ & 2.9 & -2.5 & \\
\hline \multirow{2}{*}{$2 c$} & Ser720 & $\mathrm{O}-\mathrm{H}$ & 3.04 & -0.750539 & \multirow{2}{*}{-} \\
\hline & Gly719 & $\mathrm{O}-\mathrm{H}$ & 2.86 & -2.5 & \\
\hline \multirow{4}{*}{$3 \mathrm{a}$} & Met793 & $\mathrm{O}-\mathrm{H}$ & 2.8 & -2.5 & \multirow{4}{*}{-} \\
\hline & Thr854 & $\mathrm{O}-\mathrm{H}$ & 3.03 & -2.5 & \\
\hline & Asp855 & $\mathrm{O}-\mathrm{H}$ & 2.92 & -1.56838 & \\
\hline & Lys745 & $\mathrm{O}-\mathrm{H}$ & 3 & -2.5 & \\
\hline \multirow{3}{*}{$3 b$} & Gly724 & $\mathrm{N}-\mathrm{H}$ & 3.16 & -1.74979 & \multirow{3}{*}{ Gly719 } \\
\hline & Gly724 & $\mathrm{O}-\mathrm{H}$ & 2.85 & -1.35909 & \\
\hline & Ser720 & $\mathrm{N}-\mathrm{H}$ & 2.8 & -2.5 & \\
\hline \multirow{5}{*}{$3 c$} & Lys745 & $\mathrm{O}-\mathrm{H}$ & 3.1 & -2.5 & \multirow{5}{*}{ Val726, Arg841, Gly721 } \\
\hline & Val726 & $\mathrm{O}-\mathrm{H}$ & 3.3 & -0.757545 & \\
\hline & Phe723 & $\mathrm{O}-\mathrm{H}$ & 3 & -2.5 & \\
\hline & Gly724 & $\mathrm{O}-\mathrm{H}$ & 2.65 & -2.5 & \\
\hline & Asp855 & $\mathrm{O}-\mathrm{H}$ & 2.7 & -2.5 & \\
\hline \multirow{3}{*}{$3 \mathrm{~d}$} & Met793 & $\mathrm{O}-\mathrm{H}$ & 2.8 & -2.5 & \multirow{3}{*}{-} \\
\hline & Thr854 & $\mathrm{O}-\mathrm{H}$ & 2.95 & -2.5 & \\
\hline & Lys745 & $\mathrm{O}-\mathrm{H}$ & 2.8 & -2.5 & \\
\hline $4 a$ & Phe795 & $\mathrm{O}-\mathrm{H}$ & 3 & -2.5 & - \\
\hline \multirow{2}{*}{$4 \mathrm{~b}$} & Lys745 & $\mathrm{O}-\mathrm{H}$ & 2.77 & -2.5 & \multirow{2}{*}{$\begin{array}{l}\text { Leu788, Thr790, } \\
\text { Lys745, Asp855 }\end{array}$} \\
\hline & Cys797 & N-H & 3.1 & -2.5 & \\
\hline $4 \mathrm{c}$ & Lys745 & $\mathrm{O}-\mathrm{H}$ & 3.1 & -0.195019 & $\begin{array}{l}\text { Glu762, Lys745, } \\
\text { Gly719, Asp855 }\end{array}$ \\
\hline $5 a$ & Thr854 & $\mathrm{O}-\mathrm{H}$ & 3.17 & -2.10359 & Leu844 \\
\hline \multirow{3}{*}{$5 b$} & Ser720 & $\mathrm{N}-\mathrm{H}$ & 2.7 & -2.5 & \multirow{3}{*}{ Glu762 } \\
\hline & Lys745 & $\mathrm{N}-\mathrm{H}$ & 2.7 & -1.08594 & \\
\hline & Lys745 & $\mathrm{O}-\mathrm{H}$ & 2.8 & -2.08639 & \\
\hline $5 c$ & Met793 & $\mathrm{O}-\mathrm{H}$ & 3 & -2.38289 & Val726, Leu747, \\
\hline $6 a$ & Thr854 & $\mathrm{O}-\mathrm{H}$ & 3 & -1.74103 & $\begin{array}{l}\text { Leu792, Gly796, } \\
\text { Pro794, Leu844 }\end{array}$ \\
\hline $6 b$ & Leu718 & $\mathrm{N}-\mathrm{H}$ & 3 & -2.5 & - \\
\hline
\end{tabular}




\section{Continued}

\begin{tabular}{|c|c|c|c|c|c|}
\hline $6 c$ & Thr854 & $\mathrm{O}-\mathrm{H}$ & 2.7 & -2.5 & Lys745, Met793, Val726 \\
\hline \multirow{4}{*}{$7 \mathrm{a}$} & Gly719 & $\mathrm{N}-\mathrm{H}$ & 2.85 & -1.99386 & \multirow{4}{*}{ Phe723 } \\
\hline & Lys745 & $\mathrm{O}-\mathrm{H}$ & 3.2 & -1.95469 & \\
\hline & Cys797 & $\mathrm{O}-\mathrm{H}$ & 3.3 & -1.34206 & \\
\hline & Asp800 & $\mathrm{O}-\mathrm{H}$ & 3.06 & -2.49205 & \\
\hline \multirow{5}{*}{$7 b$} & Gly719 & $\mathrm{N}-\mathrm{H}$ & 3.06 & -0.808774 & \multirow{5}{*}{ Ser720 } \\
\hline & Gly721 & $\mathrm{N}-\mathrm{H}$ & 3.1 & -0.651249 & \\
\hline & Ser720 & $\mathrm{N}-\mathrm{H}$ & 2.6 & -2.42948 & \\
\hline & Gly724 & $\mathrm{N}-\mathrm{H}$ & 3.17 & -1.54498 & \\
\hline & Gly724 & $\mathrm{O}-\mathrm{H}$ & 3 & -1.1997 & \\
\hline \multirow{2}{*}{$7 \mathrm{c}$} & Met793 & $\mathrm{O}-\mathrm{H}$ & 2.93 & -2.36929 & \multirow{2}{*}{ Lys745, Ala743 } \\
\hline & Asp855 & $\mathrm{N}-\mathrm{H}$ & 3.1 & -0.133077 & \\
\hline \multirow{3}{*}{$8 a$} & Met793 & $\mathrm{O}-\mathrm{H}$ & 3.3 & -1.22411 & \multirow{3}{*}{-} \\
\hline & Thr854 & $\mathrm{O}-\mathrm{H}$ & 2.8 & -2.5 & \\
\hline & Lys745 & $\mathrm{O}-\mathrm{H}$ & 3 & -2.5 & \\
\hline $8 b$ & Ser720 & $\mathrm{N}-\mathrm{H}$ & 2.6 & -1.84127 & Met793 \\
\hline \multirow{2}{*}{$8 c$} & Thr854 & $\mathrm{O}-\mathrm{H}$ & 2.84 & -2.5 & \multirow{2}{*}{-} \\
\hline & Lys745 & $\mathrm{O}-\mathrm{H}$ & 2.94 & -2.5 & \\
\hline
\end{tabular}

From the results, the $-\mathrm{SO}_{2} \mathrm{NH}_{2}$ group was essential for binding with the receptor. The oxazole ring in $\mathrm{R}_{1}$ gave high binding energy in comparison with other substitutes. The benzene ring in $\mathrm{R}_{2}$, which contains different substitutions such as chloro, methyl, and hydroxyl, was necessary for binding with the receptor. If the amine $\mathrm{N}_{2}$ group was free, it led to low binding energy. The absence of the amine group in $\mathrm{R}_{1}$ resulted in less binding.

All the designed compounds were bound to receptors and given energy docking, and the polar surface area represents the binding pocket of the EGFR receptor. Few compounds showed higher docking scores toward the receptor than the reference ligand, Table 3 . The compounds $4 \mathrm{~b}, 7 \mathrm{~b}$, and $6 \mathrm{c}$ were shown higher energy binding with EGFR binding pocket than other compounds.

Most of the compounds were given hydrogen bonds and van der Waals bonds to receptors with different bond lengths and binding energies. The ligand displayed hydrogen bonds with 15 amino acid residues of 2ITY: Met793, Pro794, Lys745, Cys797, Gly719, Gly721, Ser720, Gly724, Leu718, Gln791, Asp855, Thr854, Val726, Phe723, Asp800. The majority of compounds displayed van der Waals interactions between the amino acid residues and the ligands, which stabilized the compounds in the binding pocket.

The predicted binding modes of $4 \mathrm{~b}$ and $7 \mathrm{~b}$ and their interactions with the residues in the EGFR binding pocket are shown in (Figure 7). 

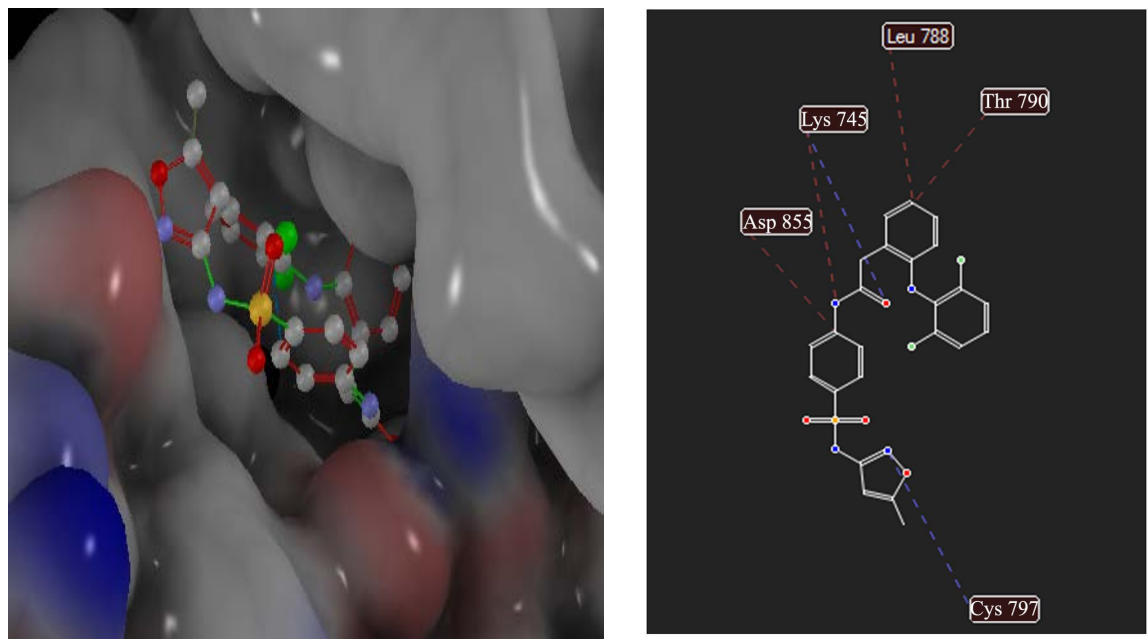

(a)
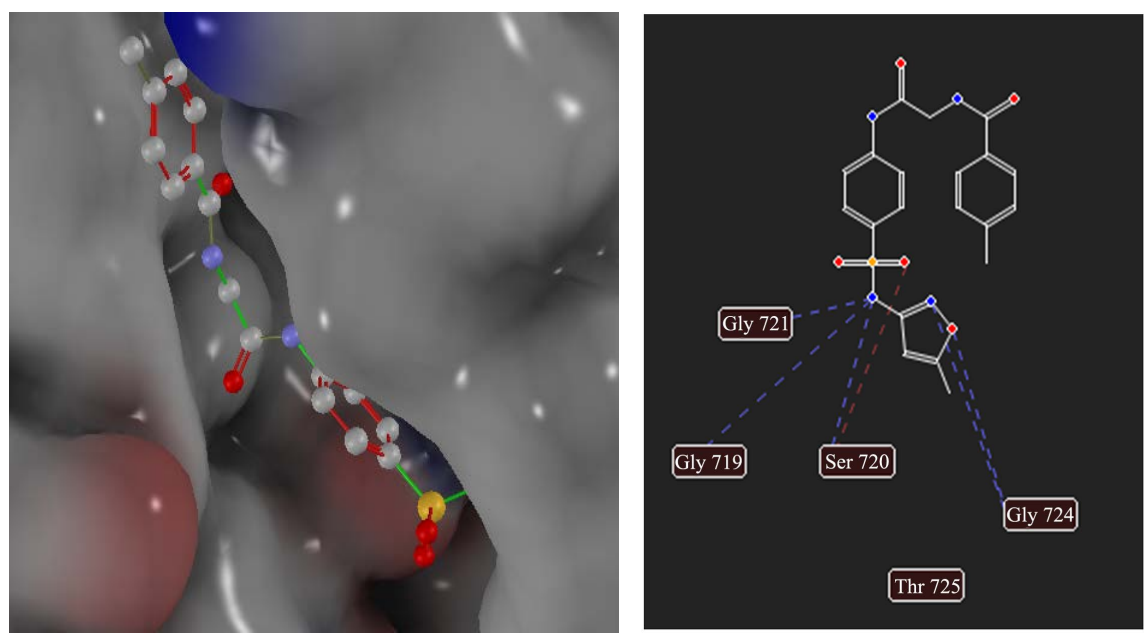

(b)

Figure 7. (a) docking solution of compound (4b) and the interactions with residues of amino acid in the EGFR binding pocket; (b) docking solution of compound (7b) and the interactions with residues of amino acid in the EGFR binding pocket. Blue bonds indicate hydrogen bonds, and red bonds indicate van der Waals.

\section{Conclusion}

Several sulfonamide derivatives were docked into the EGFR binding pocket using the Molegro Virtual Docker software. The binding free energy was calculated to predict their affinity toward EGFR kinase to select novel candidates as EGFR inhibitors for treating cancer. The results showed that $4 \mathrm{~b}$, and $7 \mathrm{~b}$ gave the highest energy docking $-128.819,-127.523 \mathrm{Kcal} / \mathrm{mol}$ toward the EGFR receptor. Their corresponding binding modes were predicted. The obtained results suggested that these compounds may be novel candidates in NSCLC lung cancer treatment by targeting EGFR tyrosine kinase; which associated with increased EGFR receptor expression in $75 \%$ of cases. More research in this area is being studied, and some designed compounds as anti-cancer agents will be synthesized. 


\section{Conflicts of Interest}

The authors declare no conflicts of interest regarding the publication of this paper.

\section{References}

[1] Irfan, A., Batool, F., Irum, S., Ullah, S. and Umer, M. (2018) A Therapeutic Journey of Sulfonamide Derivatives as Potent Anti-Cancer Agents: A Review. World Journal of Pharmaceutical Research, 7, 257-270.

[2] Peerzada, M.N., Khan, P., Ahmad, K., Hassan, M.I. and Azam, A. (2018) Synthesis, Characterization and Biological Evaluation of Tertiary Sulfonamide Derivatives of Pyridyl-Indole Based Heteroaryl Chalcone as Potential Carbonic Anhydrase IX Inhibitors and Anticancer Agents. European Journal of Medicinal Chemistry, 155, 13-23. https://doi.org/10.1016/j.ejmech.2018.05.034

[3] Mohamed, H.R.S., Shaaban, M. and Heiba, H. (2012) Synthesis of New Thiazole Derivatives Bearing a Sulfonamide Moiety of Expected Anticancer and Radiosensitizing Activities.

[4] Sudhakar, A. (2009) History of Cancer, Ancient and Modern Treatment Methods. Journal of Cancer Science and Therapy, 1, 1-4. https://doi.org/10.4172/1948-5956.100000e2

[5] Tony, B.L. (2017) Phototherapy in Cancer Prevention and Treatment. Journal of Cancer Prevention \& Current Research, 7, 22-24. https://doi.org/10.15406/jcpcr.2017.07.00224

[6] Hamed, M.M. (2013) Design and Synthesis of Novel Quinazoline-Based EGFR Kinase Inhibitors and Dual EGFR/NF- $\kappa$ B Inhibitors as Potential Anti-Cancer Drugs with Enhanced Efficacy. Diss., Universität des Saarlandes, Saarbrücken, 1-141.

[7] Abou El Ella, D.A., Ghorab, M.M., Noaman, E., Heiba, H.I. and Khalil, A.I. (2008) Molecular Modeling Study and Synthesis of Novel Pyrrolo[2,3-d]pyrimidines and Pyrrolotriazolopyrimidines of Expected Antitumor and Radioprotective Activities. Bioorganic \& Medicinal Chemistry, 16, 2391-2402. https://doi.org/10.1016/j.bmc.2007.11.072

[8] Seshacharyulu, P., Ponnusamy, M.P., Haridas, D., Jain, M., Ganti, A.K. and Batra, S.K. (2012) Targeting the EGFR Signaling Pathway in Cancer Therapy. Expert Opinion on Therapeutic Targets, 16, 15-31. https://doi.org/10.1517/14728222.2011.648617

[9] Sangande, F., Julianti, E. and Tjahjono, D.H. (2020) Ligand-Based Pharmacophore Modeling, Molecular Docking, and Molecular Dynamic Studies of Dual Tyrosine Kinase Inhibitor of EGFR. International Journal of Molecular Sciences, 21, 7779. https://doi.org/10.3390/ijms21207779

[10] Abuelizz, H.A., Marzouk, M., Ghabbour, H. and Al-Salahi, R. (2017) Synthesis and Anticancer Activity of New Quinazoline Derivatives. Saudi Pharmaceutical Journal, 25, 1047-1054. https://doi.org/10.1016/j.jsps.2017.04.022

[11] Herbst, R.S. (2004) Review of Epidermal Growth Factor Receptor Biology. International Journal of Radiation Oncology, Biology, Physics, 59, 21-26. https://doi.org/10.1016/j.ijrobp.2003.11.041

[12] Bethune, G., Bethune, D., Ridgway, N. and Xu, Z. (2010) Epidermal Growth Factor Receptor (EGFR) in Lung Cancer: An Overview and Update. Journal of Thoracic Disease, 2, 48-51.

[13] Klebl, B., et al. (2011) Protein Kinases as Drug Targets. Wiley-VCH Verlag GmbH 


\section{Co. KGaA, Weinheim.}

[14] Thirumurugan, K., Lakshmanan, S., Govindaraj, D., Daniel, D.S., Ramalakshmi, N. and Antony, S.A. (2018) Design, Synthesis and Anti-Inflammatory Activity of Pyrimidine Scaffold Benzamide Derivatives as Epidermal Growth Factor Receptor Tyrosine Kinase Inhibitors. Journal of Molecular Structure, 1171, 541-550. https://doi.org/10.1016/j.molstruc.2018.06.003

[15] El-Deeb, I.M., Bayoumi, S.M., El-Sherbeny, M.A. and Abdel-Aziz, A.A.-M. (2010) Synthesis and Antitumor Evaluation of Novel Cyclic Arylsulfonylureas: ADME-T and Pharmacophore Prediction. European Journal of Medicinal Chemistry, 45, 2516-2530. https://doi.org/10.1002/chin.201039047

[16] Saeedi, M., et al. (2014) Synthesis and Biological Investigation of Some Novel Sulfonamide and Amide Derivatives Containing Coumarin Moieties. Iranian Journal of Pharmaceutical Research, 13, 881-892.

[17] Kaur, L., Arora, V., Arora, P. and Singh, M.P. (2018) A Review: Biological Significance of Sulfonamides. World Journal of Pharmacy and Pharmaceutical Sciences, 7, 413-422.

[18] Kołaczek, A., Fusiarz, I., Lawecka, J. and Branowska, D. (2014) Biological Activity and Synthesis of Sulfonamide Derivatives: A Brief Review. Chemik, 68, 620-628.

[19] Behmadi, H., Saadati, S.M., Roshania, M. and Ghaemy, M. (2009) Synthesis of New Disulfonamides from Different Substituted Diamino Pyridines. Eclética Química, 34, 27-31. https://doi.org/10.1590/S0100-46702009000300003

[20] Rathish, I.G., et al. (2012) Synthesis and Evaluation of Anticancer Activity of Some Novel 6-aryl-2-(p-sulfamylphenyl)-pyridazin-3(2H)-ones. European Journal of Medicinal Chemistry, 49, 304-309. https://doi.org/10.1016/j.ejmech.2012.01.026

[21] Shanti, K.D., Shanti, M.D. and Meshram, J.S. (2016) A Convenient Synthesis and Molecular Docking Study of Novel Sulfonamides Fused with Betti's Bases as DNA Topoisomerase II Inhibitors. Journal of Computational Methods in Molecular Design, 6, 13-19.

[22] Rawal, K., et al. (2019) An Extensive Survey of Molecular Docking Tools and Their Applications Using Text Mining and Deep Curation Strategies. PeerJ Preprints, 7, e27538v1. https://doi.org/10.7287/peerj.preprints.27538

[23] Pinzi, L. and Rastelli, G. (2019) Molecular Docking: Shifting Paradigms in Drug Discovery. International Journal of Molecular Sciences, 20, 1-23. https://doi.org/10.3390/ijms20184331

[24] Meng, X.-Y., Zhang, H.-X., Mezei, M. and Cui, M. (2012) Molecular Docking: A Powerful Approach for Structure-Based Drug Discovery. Current Computer-Aided Drug Design, 7, 146-157. https://doi.org/10.2174/157340911795677602

[25] Christensen, M.H. (2006) MolDock: A New Technique for High-Accuracy Molecular Docking. Journal of Medicinal Chemistry, 49, 3315-3321. https://doi.org/10.1021/jm051197e

[26] Ihmaid, S., Ahmed, H.E.A. and Zayed, M.F. (2018) The Design and Development of Potent Small Molecules as Anticancer Agents Targeting EGFR TK and Tubulin Polymerization. International Journal of Molecular Sciences, 19, 408. https://doi.org/10.3390/ijms19020408

[27] Lipinski, C.A., Lombardo, F., Dominy, B.W. and Feeney, P.J. (2012) Experimental and Computational Approaches to Estimate Solubility and Permeability in Drug Discovery and Development Settings. Advanced Drug Delivery Reviews, 64, 4-17. https://doi.org/10.1016/j.addr.2012.09.019 
[28] Naaz, F., et al. (2018) Molecular Modeling, Synthesis, Antibacterial and Cytotoxicity Evaluation of Sulfonamide Derivatives of Benzimidazole, Indazole, Benzothiazole and Thiazole. Bioorganic \& Medicinal Chemistry, 26, 3414-3428.

https://doi.org/10.1016/j.addr.2012.09.019 